inscription relating to a protracted lawsuit in the time of Rameses II. In the few years which followed, Gardiner edited papyri containing admonitions and prophecies of an Egyptian sage, an account of the adventures of the courtier Sinuhe while a refugee in Palestine and a satirical literary letter addressed by one Egyptian scribe to another.

During a journey to Egypt in 1907, Gardiner's attention was directed to the much-neglected and slowly perishing tombs at Thebes, full of important representations and inscriptions. In three winter sessions, first with A. E. P. Weigall and later alone, he compiled a scientific catalogue of the 252 tombs then known, many of them discovered by himself, and later published several of the most important among them, having co-operated with the skilful draughtsman, de Garis Davies, and his wife. It is due solely to them that these important monuments of Egyptian art have beon made accessible for study in accurate copies.

In 1911 Gardiner moved from Berlin to England and settled in London to pursue his research and publications without much interruption. In 1914, at his instigation, the Journal of Egyptian Archaelogy was founded. He was for many years editor and an important contributor to this periodical. At the same time he was collecting material for his monumental Egyptian Grammar. This appeared first in 1927, and its fourth edition is about to appear posthumously - a striking proof of the popularity of the work which initiates the learner gradually into the subject according to modern methods, constantly offering exercises for translations from Egyptian to English and vice versa. In $1928 \mathrm{Mr}$. Chester Beatty entrusted him with the publication of a new find of important papyri. These appeared in two volumes about the same time as others containing late Egyptian stories and scribes' miscellanies, to be followed by administrative texts, a long fiscal document of Papyrus Wilbour and a collection of Egyptian vocabularies. The last major work, Egypt of the Pharaohs (1961), offers to the reader an account of Egyptian history and civilization as they appear to an Egyptologist as a result of a lifetime's work.

Since 1919 Gardiner had been keenly interested in general linguistics. His main work in this field, The Theory of Speech and Language, did not find unanimous approval; but Gardiner was always convinced that this book was a seed which would bear fruit at some future date. There are signs that in this he was not mistaken.

In 1915, preparing for publication with T. E. Peet the Egyptian inseriptions found by Sir Flinders Petrie at Sinai, Gardiner proposed an interpretation for a few short inscriptions written in erude hieroglyphs, but clearly not Egyptian. According to him, these are written in a hieroglyphic alphabet devised by a Semite of the region inspired by the Egyptian writing. This alphabet is the direct ancestor of all subsequent alphabets, including Greek and our own. This view of Gardiner has now been generally accepted.

J. ČERNÝ

\section{Mr. M. L. Jacks}

M. L. JACks, who died in his sleep at the age of seventy, on January 24, was a man who had given his whole life to education. He belonged to the great generation of Balliol College scholars which flowered immediately before the First World War. He was a fine classical scholar and, in the immediate post-war years, a Fellow and Dean of Wadham, but at the age of twenty-eight he became headmaster of Mill Hill School and the youngest public school headmaster in England. No one who was concerned with education in the 'thirties could ever fail to associate Jacks and Mill Hill, and the work which he did there was the sort of contribution which stands out in the history of any school.

But it was at the Department of Education in Oxford, of which Jacks became director in 1937, that he found his final life work, and it is there that he is best remem. bered to-day. He had many outside interests, but they centred in that concern for young people as individuals which informed all his work in the education and training of teachers. Perhaps because he was a great individualist himself he was one of the greatest champions of the individual child in the educational process, and he never ceased to remind his students that it was the whole child, body, mind and soul, with whom they were concerned. Whether as chairman of a committee, or lecturer or tutor, he believed in expressing fully his individual point of view and encouraging others to express theirs. Where he was, himself, in authority he had a great gift for stimulating this kind of open discussion and then finding an agreed solution which was acceptable to everybody: where he found his own hopes and ideals thwarted he was a model of patience and courtesy. It was this patient, persistent and completely selfless devotion to a cause in which he profoundly believed that enabled him, by almost imperceptible stages, to transform the position of education as a serious and acceptable study in the University. Those who have entered into his inheritance know best how rich that inheritance was.

The titles of his books, God in Education, Total Education and The Education of Good Men, express a consistent philosophy which he expounded in his lectures and exemplified in his conversation with great lucidity and a constant sense of humour. His jokes and his laughter will be remembered in Oxford as will the warmth of his personality, which was only half concealed by a surface austerity. With the foundation of the Institute of Education at Oxford in 1951 his great qualities as a lecturer became known to a much wider circle of teachers, and even after his retirement he kept up his contacts with the many schools of which he was a governor, and was always ready to meet and talk with teachers or students of education.

Both Jacks and his wife were great gardeners and amateur horticulturists, so that his retirement left them with another abiding interest. Two occasions will probably recur to the minds of those who knew him best here: the final gathering in his gardens in Surrey on the occasion of his retirement and a reunion at the Department of Education a few weeks before his death at which those who had served with him nearly thirty years ago heard him speak with all the grace and wit of his youth.

\section{A. D. C. Peterson}

\section{Dr. J. W. Broughton, M.B.E.}

Dr. JAmes W. Broughton died suddenly at his home in Ottawa, on January 21. He was born in Grimsby, England, in 1906, and went to Canada with his parents at an early age. His education in Alberta led to his graduating in 1932 with first-class honours in chemistry from the University of Alberta. He took his master's degree the next year. After a period with Imperial Oil, Ltd., in Calgary, Dr. Broughton returned to studies at MoGill University where he received his Ph.D. in 1937. He then joined the National Research Council, taking charge of the Fuels and Lubricants Laboratory of the Division of Mechanical Engineering, a position he since held continuously.

Throughout his career, Broughton made a great contribution to the development of laboratory analytical and performance methods for the evaluation of all types of petroleum products during an extremely active period in which there have been continual developments in fuels and lubricants. This work has been performed by the laboratory in collaboration with many other Federal and Provincial Government organizations, industrial labora. tories and the Royal Canadian Navy, Army and Air Force.

Dr. Broughton was widely known not only for his work in national organizations such as the Canadian Govern- 
ment Specifications Board and the various fuel and lubricant committees of the Armed Services but also internationally during his long association with the Coordinating Research Council, the American Society for Testing Metals, the Advisory Group for Aeronautical Research and Development of NATO and the International Standards Organization.

Among the more recent outstanding contributions of the laboratory have been projects concerned with coldweather lubrication, boundary lubrication and wear, and the establishment of the only lubricating oil, grease and brake fluid qualification facilities in Canada. Investi- gations have also been made on combustion problems ranging from those concerned with aviation gasoline to the ignition properties of liquid rocket propellants, and various aircraft fuel problems and hazards.

The broad experience and knowledge aequired by Dr. Broughton, readily available to others, will be sadly missed.

Dr. Broughton had many other varied interests and activities, and among them were gardening, painting and square dancing. He was also a charter member of the Delta Mu Chapter of the Phi Kappa Pi Fraternity.

D. C. MacPhant

\section{NEWS and VIEWS}

\section{The Royal Society of Edinburgh}

Prof. R. A. Rankin, Department of Mathematics, University of Glasgow, has been awarded the Society's Keith Prize for 1961-63 for his papers on the theory of numbers published in the Proceedings during the period of the award and for his earlier contributions in the same field.

\section{New Fellows}

The following have been elected Fellows of the Royal Society of Edinburgh: Mr. J. C. Bartholomew, director and chief editor, John Bartholomew and Sons, the Geographical Institute, Edinburgh 9; Dr. K. W. Bentley, chief research chemist, Joint Research Association, J. F. Macfarlan and Co., Ltd., and Reckitt and Sons, Ltd.; Prof. P. W. Brian, Department of Botany, University of Glasgow; Prof. J. I. G. Cadogan, Department of Chemistry, University of St. Andrews; Mr. H. B. Carter, senior principal scientific officer, Agricultural Research Council; Dr. G. Y. Craig, senior lecturer in geology, University of Edinburgh; Prof. A. R. Currie, Department of Pathology, University of Aberdeen; Prof. W. M. Davidson, Department of Hæmatology, King's College Hospital Medical School, University of London; Dr. R. M. Gaze, lecturer in physiology in the University of Edinburgh; Dr. D. C. Gilles, director, Computing Laboratory, University of Glasgow; Dr. J. C. Gould, senior lecturer in bacteriology, University of Edinburgh; Dr. J. K. Heyes, lecturer in the Department of Botany, University of Edinburgh; Prof. R. B. Hunter, Department of Pharmacology and Therapeutics, University of St. Andrews; Dr. S. A. Hutchinson, senior lecturer in botany, University of Glasgow; Prof. T. S. Hutchison, head of the Department of Physics, Royal Military College, Kingston, Ontario, Canada; Dr. A. Kent, leeturer in chemistry, University of Glasgow; Prof. J. D. Matthews, Department of Forestry, University of Aberdeen; Mr. A. J. Mee, H.M. Inspector of Schools, Scottish Education Department; Dr. M. W. Ovenden, lecturer in astronomy, University of Glasgow; Dr. R. W. Pringle, managing director, Nuclear Enterprises (G.B.), Ltd.; Dr. H. A. Robertson, senior lecturer in agricultural biochemistry, University of Aberdeen; Dr. J. G. Rutherglen, senior lecturer in the Department of Natural Philosophy, University of Glasgow; Dr. P. A. Sabine, chief petrographer, Geological Survey and Museum, Exhibition Road, London, S.W.7; Prof. R. S. Silver, Department of Mechanical Engineering, Heriot-Watt College; Dr. R. M. S. Smellie, senior lecturer in biochemistry, University of Glasgow; Prof. J. B. Stenlake, Department of Pharmacy, Royal College of Seience and Technology, Glasgow; Prof. T. S. Stevens, Department of Chemistry, University of Sheffield; Prof. A. S. T. Thompson, Department of Mechanical Engineering and head of the Division of Mechanical, Civil and Chemical Engineering, Royal College of Science and Technology, Glasgow.

\section{Organic Chemistry in the University of Aberdeen : \\ Prof. R. H. Thomson}

DR. R. H. Thomson has been appointed to the newly created second chair of chemistry in the University of Aberdeen with responsibilities primarily in the field of organic chemistry. Dr. Thomson, who is aged forty-three, graduated B.Sc. with Honours in the University of Leeds in 1941. He obtained his Ph.D. and his D.Sc. from the same University in 1943 and 1957, respectively. From 1943 until 1946 he was employed as a research chemist in the dyestuffs division of Imperial Chemical Industries Ltd., at Manchester. From 1946 until the present time he has been successively assistant, lecturer and senior lecturer in organic chemistry in the University of Aberdeen. He has been head of the organic section of the Department of Chemistry since 1952. Dr. Thomson's research interests have chiefly centred around the quinone group of natural and synthetic colouring matters, but have extended recently to other types of pigment, particularly those occurring in animals. Research in progress under his direction includes investigations on quinones in lichens, sea-urchins, crinoids and lugworms, flavone pigments in butterflies, ebony extractives, and the pigments in mussel shells. Dr. Thomson has established an international reputation for his work in organic chemistry and is widely regarded as a leading authority in his own field.

\section{Ministry of Aviation: $\quad$ Dr. W. H. Penley, C.B.E.}

Dr. W. H. Penciey has been appointed deputy controller of electronics at the Ministry of Aviation. He was educated at Wallasey Grammar School and the University of Liverpool, where he gained a B.Sc.(Eng.) with firstclass honours and afterwards a Ph.D. He joined the Government Service early in 1940 at the Air Ministry Research Establishment in Dundee and remained with the Establishment, which became tho Telecommunications Research Establishment, and latterly the Royal Radar Establishment, until 1962. He served in various positions and acted as director from 1961 until he was appointed director general of electronies research and development at Headquarters, Ministry of Aviation, in 1962.

\section{Mr. C. P. Fogg}

Mr. C. P. Foga has been promoted to chief scientific officer and appointed to the post of director general of electronics research and development in the Ministry of Aviation in succession to Dr. W. H. Penley. Mr. Fogg graduated at Cambridge in 1936. His first appointment was at the Research Laboratories of the General Electrio Co., Wembley, where he was engaged on television research. In 1937 he joined Sir Robert Watson Watts's radar research team at the Air Ministry Research Station, Bawdsey. During the Second World War he led a group at the Telecommunications Research Establishmont engaged on improving receiver performance and was 